\title{
Enzymatic equipment of Ascosphaera apis and the development of infection by this fungus in Apis mellifera
}

\author{
JM Alonso 1, J Rey 1, F Puerta 2,*, J Hermoso de Mendoza 1, \\ $M$ Hermoso de Mendoza 1 , JM Flores 2 \\ 1 Departamento de Medicina y Sanidad Animal, Facultad de Veterinaria de Cáceres, \\ Universidad de Extremadura 1007/1 Cáceres; \\ 2 Departamento de Ciencias Morfológicas, Sección de Biologia Aplicada, \\ Facultad de Veterinaria, Universidad de Córdoba, 14005 Córdoba, Spain
}

(Received16 October 1992; accepted 23 February 1993)

\begin{abstract}
Summary - The process of infection of honey bee brood by the fungus Ascosphaera apis was initiated by feeding 3rd instar larvae with a known dose of spores. These larvae were extracted from their sealed cells at 2 different times during early postcapping development and processed for SEM. This study was complemented with an analysis of the enzymatic equipment of the fungus, to investigate the mechanism of penetration of the larval cuticle. This analysis was conducted on mycelium isolated from mummies produced in 47 field outbreaks of chalkbrood and on 3 reference strains. There was evidence of enzymes such as $\mathrm{N}$-acetyl- $\beta$-glucosaminidase in $74.4 \%$ of the isolates, which can break down the molecules of $\mathrm{N}$-acetyl-glucosamine. Chitin, the main component of the cuticle, is a polymer composed of these molecules. This enzyme, assisted by a certain pressure from the hyphae, as these fungal elements are generated inside the larval body, may explain how the fungus pierces the cuticle.
\end{abstract}

Ascosphaera apis / Apis mellifera / larval cuticle / penetration / infection / enzyme

\section{INTRODUCTION}

The fungus Ascosphaera apis (Maassen ex Claussen) Olive and Spiltoir, is the causative agent of chalkbrood disease in the honey bee, Apis mellifera. Diseased larvae are covered by a fluffy white mould, becoming mummies when the invasion of the fungus is complete. Several histological studies have been made on larvae which developed infection by the fungus (Carrera et al, 1987; Bamford and Heath, 1989a). Nevertheless, there is controversy concerning the route of infection by $A$ apis

* Correspondence and reprints 
in the larvae, based on the evidence of penetration of the brood cuticle without production of a chitinase (Heath, 1982). Further elucidation of the mechanism of penetration during the process of infection by this fungus is needed.

\section{MATERIAL AND METHODS}

\section{Processing infected larvae for SEM}

A single dose of $5 \times 10^{5}$ spores was administered to 3 rd instar honey bee larvae. A homogeneous suspension of free spores in sterile water was obtained from 15 black mummies (Gilliam et al, 1988), mixed with honey $(50 \% \mathrm{w} / \mathrm{v})$ and fed to larvae. Concentration of spores was checked using a hemocytometer, and consumption by the larvae was confirmed by direct observation.

Pieces of comb containing groups of 22-50 individuals were kept in a commercial hive after the brood received the spores until the sealing of cells, and then transferred to an incubator, where they were kept under appropriate conditions for development $\left(30^{\circ} \mathrm{C}, 70-80 \%\right.$ relative humidity). This brood received a cooling ( $22 \pm$ $2^{\circ} \mathrm{C}$ ) during the $24 \mathrm{~h}$ following operculation. Cells were opened 36 and $51 \mathrm{~h}$ after sealing. At least 10 larvae in each group were fixed in $4 \%$ glutaraldehyde in $0.2 \mathrm{M}$ phosphate buffer and post-fixed in $1 \% \mathrm{OsO}_{4}$ in the same buffer. Specimens were dehydratated with a graded series of ethanol and dried in a critical-point drier. A Philips 501-B SEM microscope was used.

\section{Enzymatic equipment of $\mathrm{A}$ apis}

\section{Source of $A$ apis}

Three reference strains of this fungus were used: strain number 1187 (Risö National Laboratory, DK); strains NHL 2714 and SANK 11479 (National Institute of Hygienic Sciences, Tokyo, Japan). Mummies were collected from 47 field outbreaks of chalkbrood, produced in the same number of geographical localizations in Spain.
From this material, 125 non-sporulated isolates were obtained by culture in MY20 agar (Takatory and Tanaka, 1982), with $0.1 \%$ cloramphenicol added. Enzymatic studies of the reference strains were made on 2 non-sporulated isolates of each. Aseptic techniques were followed during the entire process. Identification of $A$ apis in the cultured plates was tested by:

- cross-compatibility tests with reference strains (Christensen and Gilliam, 1983);

- a morphological study of the 3 characteristic reproductive structures of the genus Ascosphaera (Von Arx, 1981; Alexopoulos and Mims, 1985) based on the measures proposed by Skou (1972). This study was made on the sporulated cultures obtained in each compatibility test.

\section{Enzymatic study}

The presence of 19 enzymatic activities were studied using the following methods.

\section{Qualitative methods}

Urease (Christensen, 1946), phosphatase, (Hankin and Anagnostakis, 1975; Cabañes et al, 1988), catalase, oxidase (Cowan and Steel, 1974; Cabañes et al, 1988) lipolytic activity (Hankin and Anagnostakis, 1975; Crippa et al, 1987), lecitinase (Mossel et al, 1967), DNAase (Hankin and Anagnostakis, 1975), RNAase (Jeffries et al, 1957; Hankin and Anagnostakis, 1975; Cabañes et al, 1988), gelatinase (Hankin and Anagnostakis, 1975; Mac Faddin, 1980), caseinolytic activity (Ahearn et al, 1968), elastase (Kothary et al, 1984), pectate lyase (Hankin et al, 1971), polygalacturonase (Van der Walt and Yarrow, 1984), amylolytic activity (Hankin and Anagnostakis, 1975; Hendrickson, 1987), cellulolytic activity (Cabañes et al, 1988) and chitinase (Hankin and Anagnostakis, 1975; Crippa et al, 1987); see Alonso (1991) for more details about the methods (table I).

\section{The semiquantitative method of API $Z Y M^{R}$ (BioMérieux) (Gilliam et al, 1989)}

In this last method, $5 \mathrm{nmol}$ of hydrolyzed substrate must be produced to consider the reaction positive. Sabouraud glucose agar was used for this test over a $7-d$ period at $30^{\circ} \mathrm{C}$. With both methods, each test was repeated twice on every isolate (table II). 
Table I. Enzymatic activities detected by qualitative methods in 3 reference strains (RS) of $A$ apis and in 125 nonsporulated isolates from 47 field outbreaks of chalkbrood.

\begin{tabular}{|c|c|c|c|c|}
\hline \multirow[t]{2}{*}{ Enzymatic activity } & \multirow{2}{*}{$\begin{array}{l}\text { Positive isolates from } \\
\text { field outbreaks (\%) }\end{array}$} & \multicolumn{3}{|c|}{ Presence in RS } \\
\hline & & $R S 1$ & $R S 2$ & $R S 3$ \\
\hline Urease & 0.0 & - & - & - \\
\hline Phosphatase & 100.0 & + & + & + \\
\hline Catalase & 100.0 & + & + & + \\
\hline Oxidase & 0.0 & - & - & - \\
\hline Lipolytic on Tween 20 & 0.0 & - & - & - \\
\hline Lipolytic on Tween 80 & 0.0 & - & - & - \\
\hline Lecitinase on SA & 0.0 & - & - & - \\
\hline Lecitinase on NA & 0.0 & - & - & - \\
\hline DNAase & 100.0 & + & + & + \\
\hline RNAase & 100.0 & + & + & + \\
\hline Gelatinase in plate & 98.4 & + & + & + \\
\hline Gelatinase in tube & 98.4 & + & + & + \\
\hline Caseinolytic & 100.0 & + & + & + \\
\hline Elastase & 0.0 & - & - & - \\
\hline Pectate lyase $(\mathrm{pH} 7)$ & 0.0 & - & - & - \\
\hline Polygalacturonase $(\mathrm{pH} 5)$ & 0.0 & - & - & - \\
\hline Amyiolytic & 100.0 & + & + & + \\
\hline Cellulolytic & 100.0 & + & + & + \\
\hline Glycogenolytic & 100.0 & + & + & + \\
\hline Chitinase & 0.0 & - & _ & - \\
\hline
\end{tabular}

RS1: $A$ apis 1187 (Denmark); RS2: A apis NHL 2714; RS3: A apis SANK 11479 (Japan); SA: Sabouraud agar; NA: nutritive agar.

\section{RESULTS AND DISCUSSION}

The image presented in figure 1 was seen in all the inoculated larvae. The surface of a honey bee larva (S) is locally raised by the fungal elements generated from inside the larval body (arrows). One of the hyphae $(H)$ has pierced the cuticle. The possible participation of a pressure mechanism in the piercing of the larval cuticle has been pointed out by Carrera et al (1987) via optic microscopy. The image presented in figure 1 may confirm this action. Results of enzymatic activity are presented in tables I and II.

Qualitative methods show a lack of variability in the enzymatic activity of isolates

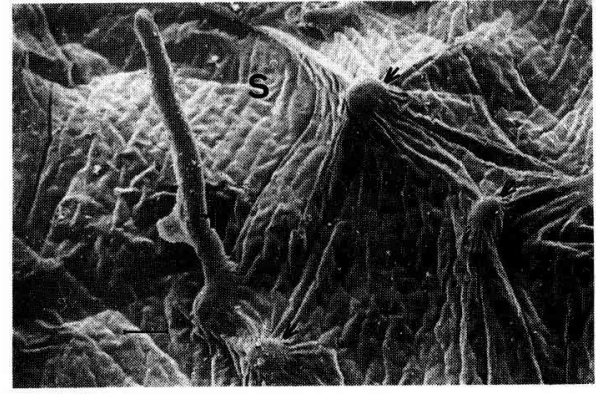

Fig 1. SEM image of the hyphae of $A$ apis piercing the larval cuticle in a honeybee prepupa. This larva received fungal spores at the 3rd instar. Bar: $5 \mu \mathrm{m}$. S: surface of the larvae; $\mathrm{H}$ : hypha piercing the cuticle; arrows: hyphae raising regions of the cuticle before piercing it. 
Table II. Enzymatic activity detected by the API ZYMR (BioMerieux) semiquantitative method in the same isolate as in table I.

\begin{tabular}{|c|c|c|c|c|}
\hline \multirow[t]{2}{*}{ Enzymatic activity } & \multirow{2}{*}{$\begin{array}{l}\text { Positive isolates from } \\
\text { field outbreaks (\%) }\end{array}$} & \multicolumn{3}{|c|}{ Presence in RS } \\
\hline & & $R S 1$ & $R S 2$ & RS3 \\
\hline Alkaline phosphatase & 100.0 & + & + & + \\
\hline Acid phosphatase & 100.0 & + & + & + \\
\hline$N$-Acetyl- $\beta$-glucosaminidase & 74.4 & - & + & + \\
\hline Esterase (C4) & 100.0 & + & + & + \\
\hline Esterase-lipase (C8) & 98.4 & + & + & + \\
\hline Lipase $(\mathrm{C} 14)$ & 0.0 & - & - & - \\
\hline Leucine aminopeptidase & 100.0 & + & + & + \\
\hline Valine aminopeptidase & 98.4 & + & + & + \\
\hline Cystine aminopeptidase & 18.4 & - & - & - \\
\hline Trypsin & 0.0 & - & - & - \\
\hline Chymotrypsin & 21.6 & - & - & - \\
\hline Phosphoamidase & 100.0 & + & + & + \\
\hline$\alpha$-Galactosidase & 0.0 & - & - & - \\
\hline$\beta$-Galactosidase & 84.8 & - & + & + \\
\hline$\beta$-Glucuronidase & 0.0 & + & + & + \\
\hline$\alpha$-Glucosidase & 80.0 & + & + & + \\
\hline$\beta$-Glucosidase & 99.2 & + & + & + \\
\hline$\alpha$-Mannosidase & 95.2 & + & + & + \\
\hline$\alpha-$ Fucosidase & 0.0 & - & - & - \\
\hline
\end{tabular}

(table 1). This homogeneity was also detected by Glinski and Osipowski (1987) and Vey (1990), and can be attributed to the seasonal migration of hives in Spain, which maintains the contact between apiaries of very diverse origin.

Catalase and phosphatase activity detected in all our isolates were previously found by Chmielewski and Glinski(1981) and Gochnauer and Margetts (1979) respectively almost in the same percentage. On the other hand, the latter authors failed to detect DNAase and RNAase activity, which we found in all our isolates, using the same method (Hankin and Anàgnostakis, 1975). With respect to protein substrates, gelatinase activity was present in $98.4 \%$ of the isolates and caseinolytic activity was present in $100 \%$. In the study by Chmielewski and Glinski (1981), only 58.7 and $1.8 \%$ of the isola- tions respectively, were found to be positive. Gochnauer and Margetts (1979) also failed to demonstrate a marked protease activity of the fungus, and concluded that $A$ apis is a relatively non-invasive parasite that kills the host by competition for primary nutrients.

Concerning the enzymatic action on carbohydrate substrates, the fungus seems to be more active than has previously been described. Amylolytic activity, which was not detected for Gochnauer and Margetts (1979) or only detected in low percentages by Chmielewski and Glinski (1981), was present in all of our isolates. Cellulolytic enzyme activity which had previously been unreported, was present in $100 \%$ of the samples. Glycogenolytic activity, described in a low proportion of samples by Kowalska (1984), was also found in $100 \%$ of the isolates, a percentage similar to that 
$(91.7 \%)$ described for this activity by Chmielewski and Glinski (1981).

Our results also confirm the lack of chitinase production by $A$ apis (Huber, 1958; Gochnauer and Margetts,1979; Chmielewski and Glinski, 1981; Kowalska, 1984). This is important in relation to the mechanism of penetration of the larval cuticle by the fungus.

Results presented in table II confirm the presence of phosphatase activity, both alkaline and acid phosphatase, in $100 \%$ of the isolates.

$N$-acetyl- $\beta$-glucosaminidase activity was present in $74.4 \%$ of the isolates. A study by Gochnauer and Margetts (1979) failed to demonstrate the presence of chitinase and other crucial lytic enzymes; Bamford and Heath (1987) suggested that bound enzymes may be involved in the mechanism of cuticular penetration by the fungus. The mechanism of penetration of the larval cuticle by the fungus might be explained by a combined action, a selective attack on the monomers of $N$-acetyl- $\beta$-glucosamine which composes the chitin, and a pressure mechanism by the hyphae generated from below the cuticle, as described before. Insect cuticle is composed of lipids and proteins in addition to chitin (Richard and Davies, 1983; Boucias and Latge, 1988). The presence of lipolytic and proteolytic enzymatic activities (esterase, esterase-lipase, leucine and valine aminopeptidase) found by the API ZYMR method in almost all the isolates, may be complemented by the action on proteic substrates found by qualitative methods.

The API ZYMR system also confirmed that $A$ apis shows extensive enzymatic equipment for the degradation of carbohydrates. A high percentage of isolates produced $\beta$-galactosidase, $\alpha$-glucosidase, $\beta$ glucosidase, and $\alpha$-mannosidase.

The percentage of isolates found to be positive for various enzymatic activities co- incides with that detected in the reference strains, both by the qualitative as well as by the semiquantitative method (tables I, II).

By the use of these 2 methods for enzyme analyses, it can be seen that $A$ apis develops an extensive enzymatic activity in the main components of the cuticle. Infection from ingested material would probably lead to a complementary mechanism for piercing of the larval cuticle, supported by the pressure produced by hyphae when these elements are generated from inside the larval body. If the fungus can proliferate from the surface of the brood, as has been pointed out by several authors (Gilliam et al, 1978; Glinski, 1981), enzymes would have to carry out the piercing of the cuticle without internal hyphal pressure contribution.

$A$ apis appears to have a life-cycle which is highly adapted to the development of the honeybee brood. Bamford and Heath (1989b), in a study of the effects of environmental temperature and $\mathrm{pH}$ on the germination of $A$ apis, have pointed out that the fungus is better adapted to germinate within a larva than on its surface. The wide range of mechanisms for degradation of carbohydrates would contribute to rapid growth inside the larval gut contents. The stage at which penetration of the gut wall usually takes place coincides with the destruction of the midgut cells, providing hyphae with an easy route thoughout the larval body (Heath, 1982). By the time the hyphae reach the surface cuticle, the bee larva is dead, so its own protolytic and other enzymes could contribute to cuticle breakdown. Besides, when the fungus reaches this cuticle, its hyphae have grown sufficiently to develop a strong pressure on this structure and, leaning on the underlying tissues, the proteolytic, lipolytic and $N$ acetyl- $\beta$-glucosaminidase action combine with this mechanical effect. All these circumstances would not be present in the case of surface infections. 


\section{ACKNOWLEDGMENTS}

Funds were provided by the National Institute for Agricultural Research (INIA, Spain). We thank F Aceituno, M Arroyo, J Cruz, V López, JJ Macías, A Marcos, G Pérez, M Muñiz, M Ferrer, and the Apicultural Associations of Barcelona, Burgos, Ciudad Real, Galicia, Gijón, Granada, Pontevedra, Seville, Tarragona, Valencia, Vizcaya, for their collaboration in providing us with mummies. We thank the anonymous reviewers for making useful suggestions concerning the manuscript.

Résumé - L'équipement enzymatique d'Ascosphaera apis et le développement de l'infection chez l'abeille, Apis mellifera. On déclenche l'infection du couvain par le champignon Ascosphaera apis en administrant à des larves de $3^{\text {e }}$ stade une dose connue de spores. Des larves ont été extraites de leur cellule operculée $36 \mathrm{~h}$ ou $51 \mathrm{~h}$ après l'operculation, et traitées pour être observées au microscope électronique à balayage. Cette étude est complétée par une analyse de l'équipement enzymatique du champignon, afin de comprendre le mécanisme de pénétration de la cuticule larvaire. L'analyse a été faite sur des myceliums obtenus à partir de momies prélevées dans 47 foyers de couvain plâtré, et sur 3 souches de référence, selon des méthodes qualitatives et semiquantitatives (API ZYMR, BioMérieux) (tableau I et II) Bien qu'on n'ait pas détecté d'activité nettement chitininasique dans les isolements, on note la présence évidente, dans une partie des échantillons analysés, d'enzymes tels que l'acétyl glucosaminidase. Cet enzyme peut attaquer les monomères de $\mathrm{N}$-acétyl glucosamine qui composent la chitine, principal composant de la cuticule. Cette action enzymatique, aidée d'une certaine pression mécanique des hyphae quand ces éléments fongiques sont générés depuis l'intérieur du corps larvaire (fig 1), peut expliquer com- ment le champignon traverse la cuticule. La présence d'un vaste arsenal enzymatique destiné à la dégradation des sucres confirme que $A$ apis est un agent pathogène des larves d'abeille hautement spécialisé.

Ascosphaera apis / Apis mellifera / cuticule larvaire / pénétration / infection / enzyme

Zusammenfassung - Enzymatische Ausstattung von Ascosphaera apis und Entwicklung der von diesem Pilz hervorgerufenen Infektion bei Apis mellifera. Der Infektionsablauf wurde hervorgerufen, indem man Larven im 3.Stadium eine bekannte Dosis von Sporen des Pilzes Ascosphaera apis eingab. Die für das REM präparierten Larven stammten aus verdeckelten Zellen, die man zu zwei verschiedenen Zeitpunkten entnahm (36 und 51 Stunden nach Verdeckelung der Zellen). Diese Studie wurde durch eine Analyse des enzymatischen Arsenals des Pilzes vervollständigt, um den Penetrationsmechanismus durch die Kutikula der Larve aufzuklären. Die Untersuchung wurde mit aus Mumien isolierten Myzelien durchgeführt, welche aus 47 Epizootien der Kalkbrut und 3 Stämmen als Referenz stammen, wobei qualitative und halbquantitative Methoden (API ZYMR, BioMérieux) angewandt wurden (Tabelle I und II). Obwohl in keiner der isolierten Proben Enzyme nachgewiesen wurden, die ausschließlich das Chitin angreifen, ist es offensichtlich, daß 74,4\% der isolierten Proben Enzyme wie die Acetylglukosaminase enthalten, die die Kette des Chitins aufbrechen können. Das Chitin ist ein Polymer, das sich aus N-Acetylglukosaminmolekülen zusammensetzt und ein Hauptbestandteil der Kutikula bildet. Diese enzymatische Wirkung, zusammen mit dem mechanischen Druck, den die 
Hyphen aus dem Inneren der Larve herauswachsend ausüben (Abb 1), kann die Penetration der Kutikula durch den Pilz erklären. Das Vorhandensein eines umfassenden enzymatischen Arsenals für den Abbau von Zuckern bestätigt, daß Ascosphaera apis einen hochspezialisierten Krankheitserreger der Bienenlarve darstellt.

\section{Ascosphaera apis / Apis mellifera / Lar- venkutikula / Durchdringung / Infek- tion / Enzyme}

\section{REFERENCES}

Ahearn DG, Meyers SP, Nichols RA (1968) Extracellular proteinases of yeast and yeast-like fungi. Appl Microbiol 16, 101-108

Alexopoulos CJ, Mims CW (1985) Introducción a la Micología. Omega, Barcelona, Spain, 290-291

Alonso JM (1991) La ascosferiosis en Apis mellifera en España. Ph thesis, Ed Universidad de Córdoba, Córdoba, Spain, 312-334

Bamford S, Heath LAF (1989a) The infection of Apis mellifera larvae by Ascosphaera apis. J Apic Res 28(1), 30-35

Bamford S, Heath LAF (1989b) The effects of temperature and $\mathrm{pH}$ on the germination of spores of the chalkbrood fungus, Ascosphaera apis. J Apic Res 28(1), 36-40

Boucias D, Latge JP (1988) Fungal elicitors of invertebrate cell defense system. In: Fungal Antigens (Drouhet E,ed) Plenum Publ Co, NY, 121-137

Cabañes FJ, Abarca L, Bragulat MR, Brugera $T$, Calvo MA (1988) Determinación de actividades enzimáticas en cepas del género Epidermophyton. Rev lber Micol 5 (2), 63-73

Carrera P, Sommaragua A, Vailiti G (1987) The development of Ascosphaera apis within larvae of Apis mellifera ligustica. J Apic Res 26 (1), 59-63

Chmielewski M, Glinski Z (1981) Studies on pathogenicity of Ascosphaera apis for larvae of the honeybee (Apis mellifera L). Part I. Biochemical properties of $A$ apis. Ann Univ $M$ Curie-Sklodowska 36(8), 71-82
Christensen WD (1946) Urea descomposition as means of differentiating Proteus and Paracolon cultures from each other and from Salmonella and Shigella types. J Bacteriol 52, 461466

Christensen M, Gilliam M (1983) Notes on Ascosphaera species inciting chalkbrood in honey bees. Apidologie 14(4), 291-297

Cowan ST, Steel KJ (1974) Identification of Medical Bacteria. Cambridge Univ Press, 2nd edn

Crippa A, Bruno E, Mangiarotti AM, Caretta G (1987) Extracellular enzymatic activities of 32 fungal species. Bol Mico/3(2), 129-134

Gilliam M, Taber S, Rose JB (1978) Chalkbrood disease in the honey bee, Apis mellifera L: a progress report. Apidologie 9(1), 75-89

Gilliam M, Taber S, Lorenz BJ, Prest DB (1988) Factors affecting development of chalkbrood disease in colonies of honeybees Apis mellifera fed pollen contaminated with Ascosphaera apis. J Invertebr Pathol 52, 314-325

Gilliam M, Prest DB , Lorenz BJ (1989) Microbiology of pollen and bee bread: Taxonomy and enzymology of molds. Apidologie 20(1), 53- 68

Glinski $Z$ (1981) Studies on the effect of the fungus Ascosphaera apis on the larvae of the honeybee, Apis mellifera L. Polsk Arch Wet 23, 9-15

Glinski Z, Osipowski T (1987) The influence of nystatin and sanitary and breeding operations on the control of chalkbrood disease of the honeybee. Ann Univ M Curie Skolodowska 39, 217-226

Gochnauer TA, Margetts VJ (1979) Properties of honeybee larvae killed by chalkbrood disease. J Apic Res 18(3),212-216

Hankin L, Zucker M, Sands DC (1971) Improved solid medium for the detection and enumeration of pectolytic bacteria. App/ Microbio/ 22 , 205-209

Hankin L, Anàgnostakis SL (1975) The use of solid media for detection of enzyme production by fungi. Mycologia 67, 597-607

Heath LAF (1982) Development of chalkbrood in a honeybee colony: a review. Bee World 63 (3), $119-130$

Hendrickson DA (1987) Rectivos y colorantes. In: Manual de Microbiología Clínica. Medica Panamericana, Buenos Aires, 1353-1370 
Huber J (1958) Untersuchungen zur Physiologie insektentötender Pilze. Arch Mickrobiol 29 (3), 257-276

Jeffries CD, Holtman DF, Guse DG (1957) Rapid method for determining the activity of microorganisms on nucleic acid. J Bacteriol 73 , 590-591

Kothary MH, Chase T, MacMillan JD (1984) Correlation of elastase production by some strains of Aspergillus fumigatus with ability to cause pulmonary invasive aspergillosis in mice. Infect Imm 43(1), 320-325

Kowalska M (1984) Biochemical properties of Ascosphaera apis and Bettsia alvei. Polsk Arch Wet 24(1), 7-15

Mac Faddin JF (1980) Pruebas Bioquímicas Para la Identificación de Bacterias de Importancia Clínica. Medica Panamericana, Buenos Aires

Mossel DA, Koopman MJ, Jongerius E (1967) Enumeration of Bacillus cereus in foods. Appl Microbiol 15, 650-653
Richards OW, Davies RG (1983) El tegumento. In: Tratado de Entomologia Imms. Omega, Barcelona, Spain, vol 1, 14-27

Skou JP (1972) Ascosphaerales. Friesia 10(1), $1-24$

Takatori K, Tanaka I (1982) Ascosphaera apis isolated from chalkbrood in honey bees. Jpn J Zootech Sci 53(2), 89-92

Van der Walt JP, Yarrow D (1984) Methods for isolation, maintenance and classification. $\mathrm{In}$ : The Yeast, a Taxonomic Study (Kreger van Rij NJW, ed) Elsevier, Amsterdam, 76-79

Vey A (1990) Recent studies on ascosphaerosis. In: Proc Int Sym Recent Res Bee Pathology (Ritter W, ed) Apimondia, Ghent, Belgium, 140-143

Von Arx JA (1981) The Genera of the Fungi Sporulating in Pure Culture (Cramer J, ed) Gantner Verlag, Komm Vaduz, 3rd edn, 118, 138-139 